\title{
Hematemesis on Hepatic Cirrhosis Patients in Area with Limited Facilities
}

\author{
Yudha Klahan $^{1 *}$, Firas Farisi Alkaff ${ }^{2}$ \\ ${ }^{1}$ dr. M.M. Dunda Limboto General Hospital, Gorontalo, Indonesia \\ ${ }^{2}$ Faculty of Medicine, Universitas Airlangga, Surabaya, Indonesia
}

\author{
A R T I CLE IN FO \\ Article history: \\ Received 4 April 2018 \\ Received in revised form 23 April \\ 2018 \\ Accepted 23 April 2018 \\ Keywords: \\ Hematemesis \\ Esophageal varices \\ Hepatic Cirrhosis. \\ *) Corresponding author: \\ klahanxix@gmail.com
}

\begin{abstract}
A B S T R A C T
Esophageal variceal haemorrhage is one of the more dangerous complications of hepatic cirrhosis. Initial treatment can determine patient mortality and morbidity. But not all hospitals have adequate facilities and medicines to handle it. The 53-year-old woman came with a diagnosis of ascites and hematemesis. At the initial examination found hypotension. Laboratory results show anemia, thrombocytopenia, and leukocytosis. The next morning the patient's condition worsened and was transferred to ICU. During the ICU patients receive $10 \mathrm{lpm}$ oxygen support, cefobactam, pantoprazole, PRC transfusion, and dopamine. Patients begin conscious on the 5th day of treatment. Then the patient started getting diuretics on day 6 and propranolol on day 9. On day 13 the patient's condition improved and the patient was discharged for outpatient treatment. Limitations of the endoscopic tool cause not every hospital in Indonesia can perform emergency endoscopy for therapy. However, with rapid and appropriate pharmacological therapy, patients can be helped not to fall into mortality and prevent recurrent bleeding.
\end{abstract}

Introduction

Esophageal variceal haemorrhage is one of the more dangerous complications of hepatic cirrhosis. In hepatic cirrhosis, hepatic architecture changes due to liver cell necrosis become regenerative nodules (1). This change causes increased blood flow and resistance in the portal vein. Portal hypertension leads to dilatation of blood vessels especially those from the azygos vein, which then causes varicose veins in the gastrointestinal tract (2).

Esophageal varices are closely related to the severity of hepatic cirrhosis. Approximately 30\% of newly diagnosed patients with hepatitis cirrhosis already have varicose veins and increase to $90 \%$ after 10 years (3). Severe liver disease (Child-Pugh C) has a greater risk of esophageal variceal haemorrhage than patients with milder liver disease (Child-Pugh A and B)(4).
Approximately $30 \%$ or $1 / 3$ of patients with esophageal varices will experience bleeding within 1 year after diagnosis (5). Mortality within six weeks of bleeding is about $15-20 \%$, ranging from $0 \%$ in patients with grade A children to about $30 \%$ of patients with grade $\mathrm{C}$ (2). If not in therapy, esophageal varices mortality is $20-60 \%$, but if therapy was done then the mortality decreased to $20 \%$ (4).

The initial treatment of bleeding in the gastrointestinal tract can determine the patient's mortality and morbidity, so it should be handled rapidly and appropriately. Not all hospitals have adequate facilities and medicines to deal with, therefore we want to share case reports of severe hematemesis handling in limited facilities. 


\section{Cases Illustration}

Fifty three years old woman referral from Puskesmas (Pusat Kesehatan Masyarakat/Community Health Center) Buladu came to RS M.M. Dunda District Gorontalo, with diagnosis of ascites and hematemesis. Swelling of the entire body was felt long ago, first swelling felt in the legs and stomach. The stomach felt bigger and tense but did not make breathless. Patients feel nausea and decreased appetite, heat loss, and dizziness since 5 days ago. Vomiting and black defecation since 2 days ago, vomiting $>5 \mathrm{x}$ daily volume of approximately 1 glass of water glass package (around $250 \mathrm{ml}$ ). The patient felt lethargic, unable to stand and consciousness begins to apathetic. History of diabetes mellitus and hypertension was refuted, history of taking painkillers was denied.

Based on the initial physical examination of the clock obtained GCS E4M6V5, compos mentis, hypotension 90/60, normal pulse $88 \mathrm{x} / \mathrm{m}$. Conjuctiva anemic, larged abdomen with undulation tests and shifting dullness positive, rough ronkhi in both basal lung, and anasarka edema. Laboratory tests obtained very low hemoglobin, accompanied by leukocytosis and thrombocytopenia (Table 1). Patients were diagnosed with hematemesis and melena et causa esophageal varices of dd gastritis erosiva and acute kidney failure. Initial therapy was given infusion of $0.9 \% \mathrm{NaCl}$ ruwatan, chrome, tranexamic acid, omeprazole, and sucralfat syrup.

Table 1. Result of Laboratorium Examination

\begin{tabular}{lllll} 
Parameter & 07-Feb & 11-Feb & $15-\mathrm{Feb}$ & 20-Feb \\
\hline $\mathrm{Hb}$ & 2,5 & 4,3 & 6,5 & 9,2 \\
Leu & 21,6 & 10,7 & 6,42 & 8,85 \\
Tro & 20 & 97 & 85 & 88 \\
Hct & $9,60 \%$ & $12,3 \%$ & $17 \%$ & $28,70 \%$ \\
Ery & 1,24 & 1,73 & 2 & 3,41 \\
\hline
\end{tabular}

The patient's condition then worsens, the morning GCS decreases E1M3V1 and blood pressure 100/50. Once NGT installed black blood obtained as much as $750 \mathrm{cc}$. Patients mounted non-rebreathing mask 10 lpm, cefobactam antibiotic $2 \times 1 \mathrm{gr}$, omeprazole replaced with pantoprazole, patient was recommend to fasting, PRC transfusion, dopamine syringe pump, and patients treated in ICU.

Examination of thorax photograph obtained by cardiomegaly accompanied by sign of pulmonary dam and minimal effusion of sinus pleura. Abdominal ultrasound acquired hepatic cirrhosis with massive ascites with splenomegaly is considered hypertensive portal (Fig. 1).

Treatment on the day 5, the patient was conscious GCS E4M6V5 and blood pressure 110/60, dopamine titration began to be lowered. Day- 6 the patient's blood pressure was stable 120/80 still with dopamine, then the patient was given furosemid 1-1-0, and spironolacton $1 \mathrm{x}$ $25 \mathrm{mg}$. The 8th day of antibiotic and chromed administration was discontinued, the dose of furosemide was raised to 2-1-0. Day 9 the patient given propanolol 3 $\mathrm{x}$ 10mg. Day-13 patient condition stabilized compos mentis consciousness, blood pressure $110 / 60$, pulse $75 \mathrm{x} /$ min, breath $24 \mathrm{x} /$ minute, and temperature $360 \mathrm{C}$. Laboratory examination showed improvement in hemoglobin, leukocyte, and platelet counts (table 1). The patient was then discharged for outpatient care.

\section{Discussion}

The first step in treating upper GI bleeding is to identify the source of bleeding, whether variceal or non-variceal. Variceal hemorrhage is generally followed by signs of hepatic failure and portal vein hypertension such as ascites, gynecomastia, spider nevi, palmar erythema (6). Then evaluate the degree of patient bleeding, plug double IV line, prepare ICU space, intubation, and access the central vein (CVC). Perform fluid resuscitation with blood pressure target $>80 \mathrm{mmHg}$ and transfusion with target $\mathrm{Hb}>8 \mathrm{~g} / \mathrm{dl}$ (7).

Strict supervision due to too much fluid/transfusion in patients with variceal hemorrhage may aggravate bleeding due to intravascular volume increase, and result in complications of pulmonary edema and ascites after hemostasis is reached (8). This patient was initially given only ruwatan liquids because the blood pressure target was reached $90 / 60$, but the inborn $\mathrm{Hb}$ was very anemic 2.5 and the maximum cito blood was only 2 bag/day.

Give splanic vasoconstrictor therapy such as terlipressin or somatostatin. Ditipresin modifies the hemodynamic system by decreasing cardiac output and increasing arterial blood pressure and systemic vascular resistance. When suspected variceal bleeding, patient was given a dose of $2 \mathrm{mg} / \mathrm{h}$ for the first 48 hours and continued for up to 5 days then the dose was decreased 1 $\mathrm{mg} / \mathrm{h}$ or 12-24 $\mathrm{h}$ after bleeding stopped (4). Somatostatin was given 250 dose loading dose and then continued with dextrose dextrose $5 \% \quad 250 \mu \mathrm{g} / \mathrm{h}$ (6 mg/day) (8). Antibiotic prophylaxis was given to treat infections such as spontaneous bacterial peritonitis. Selected antibiotics of ceftriaxone or quinolone may be administered orally or IV, for 7 days (7). In this patient due to limited available drugs, there was no vassopressin drug, while antibiotics are given cefobactam 2 x 1 gr.

Endoscopic therapy is the primary choice in the treatment of variceal bleeding, and should be done in less than 12 hours after bleeding. Visual endoscopy can differentiate the location of varicose veins, whether in the esophagus or gastric, the choice of therapy may be by ligation or sclerotherapy (7) (figure 2). In this case, the hospital actually has an endoscope but only as a diagnostic tool, so that the patient is considered endoscopic after a stable vital condition. 
Table 2. Comparison of mortality risk and re-bleeding with combination therapy (9)

\begin{tabular}{lll}
\hline Management & $\begin{array}{l}\text { Rebleeding } \\
\text { report }\end{array}$ & $\begin{array}{l}\text { Mortality } \\
\text { report }\end{array}$ \\
\hline $\begin{array}{l}\text { No } \\
\text { management }\end{array}$ & $55-67 \%$ & $23-64 \%$ \\
\hline Inhibitor B & $37-57 \%$ & $13-39 \%$ \\
\hline EIS & $34-53 \%$ & $18-36 \%$ \\
\hline EIS \\
inhibitor B & $19-49 \%$ & $7-26 \%$ \\
\hline EBL & $20-43 \%$ & $19-34 \%$ \\
\hline $\begin{array}{l}\text { Inhibitor B }+ \\
\text { ISMN }\end{array}$ & $30-42 \%$ & $12-32 \%$ \\
\hline TIPS & $12-22 \%$ & $18-35 \%$ \\
\hline DSRS & $11-31 \%$ & $22-55 \%$ \\
\hline
\end{tabular}

$\mathrm{EIS}=$ endoscopic injection sclerotherapy, $\mathrm{EBL}=$ endoscopic

band ligation, ISMN=isosorbide-5-mononitrate,

TIPS=transjugular intrahepatic portal-systemic shunt,

DSRS=distal splenorenal shunt.

Once the severity is resolved and the blood pressure stable, the patient may be given a non-selective $\beta$ adrenergic inhibitor in combination with the isonorbid mononitrate. Drugs are given orally as long-term therapy to prevent recurrence by decreasing cardiac output and splanic vasoconstrictors (9). The combination of propanolol and ISMN may decrease the incidence of recurrent bleeding by $19-49 \%$, while a combination of sclerotherapy and propanolol is likely to be $30-42 \%$ (9, 10) (table 2).

Choice of nonselective $\beta$-adrenergic drug may be propanolol or nadolol. Propanolol can be started from 20 $\mathrm{mg}$ per oral 2 times a day and nadolol $40 \mathrm{mg}$ per oral $1 \mathrm{x} /$ day. The dose is increased to a maximum tolerable dose or pulse frequency of $55 \mathrm{x} / \mathrm{min}$. Ligation of endoscopic varicose can be done every 2-4 weeks will usually occur obliteration after 2-4 sessions, then the first surveillance done 1-3 months after obliteration then every 6-12 months. ISMN is given at an initial dose of $10 \mathrm{mg}$ per oral per night, increased to a maximum dose of $2 \times 20 \mathrm{mg}$ daily or blood pressure $>95 \mathrm{mmHg}$ (10)

\section{Conclusion}

Esophageal varices are dilated submucous portion of veins into the esophagus, occurring in patients with portal hypertension and may cause serious upper GI bleeding. All patients with variceal bleeding require endoscopic examination which is the standard standard for diagnosis, assessing possible varicose veins and management based on the underlying disease.

The limitations of expensive endoscopic devices and rare operator personnel make not every hospital in Indonesia can perform emergency endoscopes. However, with rapid and appropriate pharmacological therapy, it can help patients not to fall into mortality and prevent recurrent bleeding.

\section{Conflict of Interest}

The author stated there is no conflict of interest

\section{References}

1. Nurdjanah S. Sirosis Hati. In: Sudoyo AW, Setiyohadi B, Alwi I, Simadibrata M, Setiati S, editors. Buku Ajar Ilmu Penyakit Dalam. 4 ed. Jakarta: Pusat Penerbitan Departemen Ilmu Penyakit Dalam Fakultas Kedokteran Universitas Indonesia; 2006. p. 443-6.

2. Garcia-Tsao G, Bosch J. Varices and Variceal Hemorrhage in Cirrhosis: A New View of an Old Problem. Clinical gastroenterology and hepatology : the official clinical practice journal of the American Gastroenterological Association. 2015;13(12):2109-17.

3. World Gastroenterology Organisation. World Gastroenterology Organisation Global Guidelines: Esophageal Varices. Milwaukee: World Gastroenterology Organisation; 2014. p. 1-14.

4. Netiana, Juniati SH. Esophageal varices. Jurnal THT-KL. 2010;3(2):15 pages.

5. Benedeto-Stojanov D, Nagorni A, Bjelaković G, Milanović J, Stojanov D. Predictive Factors of Bleeding from Esophageal Varisces in Patient with Liver Cirrhosis and Portal Hypertension. Facta Universitatis. 2006;12(3):164-7.

6. Vidyani A, Vianto D, Widodo B, Kholili U, Maimunah U, Sugihartono T, et al. Faktor Risiko Terkait Perdarahan Varises Esofagus Berulang Pada Penderita Sirosis Hati. Jurnal Penyakit Dalam. 2011;12(3):169-74.

7. Bendtsen F, Krag A, Moller S. Treatment of acute variceal bleeding. Digestive and liver disease : official journal of the Italian Society of Gastroenterology and the Italian Association for the Study of the Liver. 2008;40(5):328-36.

8. Kim YD. Management of acute variceal bleeding. Clinical endoscopy. 2014;47(4):308-14.

9. Karjadi T, Widjaja FF. Prevention of Recurrent Bleeding in Liver Cirrhosis Patient. Journal of the Indonesian Medical Association. 2011(Vol. 61 No. 10 October 2011).

10. Bosch J, Garcia-Pagan JC. Prevention of variceal rebleeding. Lancet. 2003;361(9361):952-4. 